\title{
Efektivitas Biomatriconditioning Benih Pratanam yang diintegrasikan dengan Aplikasi Pestisida Nabati terhadap Pertumbuhan dan Hasil Bawang Merah True Seed
}

\section{The Effectiveness of Pre planting Seed Biomatriconditioning which is integrated with the Application of Botanical Pesticides on the Growth and Yield of True Seed Shallots}

\author{
Anaway F. ${ }^{1}$, Gusti Ayu Kade Sutariati ${ }^{2 *}$ dan La Ode Santiaji Bande ${ }^{3}$ \\ ${ }^{1}$ Program Studi Magister Agronomi Pascasarjana Universitas Halu Oleo \\ 2 Jurusan Agroteknologi Fakultas Pertanian Universitas Halu Oleo \\ ${ }^{3}$ Jurusan Proteksi Tanaman Fakultas Pertanian Universitas Halu Oleo
}

Diterima: 15 Maret 2021 / Disetujui: 26 Juli 2021

\begin{abstract}
ABSTRAK
Penggunaan true seed untuk produksi umbi bibit ataupun umbi konsumsi belum banyak dilakukan oleh petani bawang merah di Indonesia. Penyebabnya antara lain ketersediaan true seed masih terbatas dan belum ditemukannya teknologi pembibitan dan pembudidayaan bawang merah dari true seed yang efisien. Penelitian ini bertujuan untuk menganalisis efektivitas perlakuan biomatriconditioning pada true seed pratanam yang diintegrasikan dengan aplikasi pestisida nabati terhadap pertumbuhan dan hasil bawang merah. Penelitian ini menggunakan Rancangan Acak Kelompok Faktorial dengan faktor pertama yaitu agens hayati terdiri dari 4 taraf yakni tanpa perlakuan invigorasi (B0), arang sekam + Bacillus CKD061 (B1), arang sekam + Pseudomonas SWRII B02 (B2), arang sekam + Pseudomonas W2R06 (B3) dan faktor kedua yaitu aplikasi pestisida nabati terdiri atas 3 taraf yakni tanpa aplikasi pestisida nabati (P0), 4 kali aplikasi pestisida nabati (P1) dan 2 kali aplikasi pestisida nabati (P2). Variabel yang diamati adalah tinggi tanaman, jumlah daun, diameter batang, jumlah anakan, luas daun, laju asimilasi bersih, diameter umbi, berat segar umbi dan kesehatan tanaman. Data pengamatan dianalisis ragam dan data analisis yang menunjukkan pengaruh nyata atau sangat, dilanjutkan dengan uji jarak berganda duncan pada taraf nyata $\alpha=0,05$. Hasil penelitian menunjukkan bahwa secara mandiri perlakuan biomatriconditioning benih berpengaruh terhadap semua peubah yang diamati, sementara perlakuan aplikasi pestisida nabati hanya berpengaruh terhadap peubah jumlah daun, diameter batang, luas daun dan laju asimilasi bersih. Interaksi perlakuan biomatriconditioning benih dan aplikasi pestisida nabati berpengaruh terhadap tinggi tanaman, luas daun dan laju asimilasi bersih. Perlakuan terbaik diperoleh pada biomatriconditioning benih menggunakan isolat Bacillus CKD061 yang diintegrasikan dengan aplikasi pestisida nabati 2 kali (10 HST dan 30 HST).
\end{abstract}

Kata kunci: Aplikasi pestisida nabati, Biomatriconditioning, true seed

\section{ABSTRACT}

The use of true seeds for the production of seed tubers or tubers for consumption has not been widely used by shallot farmers in Indonesia. The reasons, among others, are still limited availability of true seeds and the absence of efficient technology for seeding and cultivating shallots from true seeds. This study aims to analyze the effectiveness of biomatriconditioning treatment on preplanting true seeds integrated with the application of botanical pesticides on the growth and yield of shallots. This study was design using a factorial randomized block design with the first factor, namely biological agents consisting of 4 levels, i.e. without invigoration treatment (B0), husk charcoal + Bacillus CKD061 (B1), husk charcoal + Pseudomonas SWRII B02 (B2), husk charcoal + Pseudomonas W2R06 (B3) and the second factor is the application of botanical pesticides consisting of 3 levels, i.e. without the application of botanical pesticides (P0), 4 times application of botanical pesticides (P1) and 2 times application of botanical pesticides (P2). The variables observed were plant height, number of leaves, stem diameter, number of tillers, leaf area, net assimilation rate, tuber diameter, tuber fresh weight and plant health. The observational data were analyzed using analysis of variance. Data result that showed significant or most significant effects, followed by Duncan's multiple distance test at the level $\alpha$ $=0.05$. The results showed that independently the biomatriconditioning treatment of seeds affected all observed variables, while the application of botanical pesticides only affected the variables of leaf number, stem diameter, leaf area and net assimilation rate. The interaction of seed biomatriconditioning treatment and application of botanical pesticides affected plant height, leaf area and net assimilation rate. The biomatriconditioning of seeds using isolate Bacillus CKD061 which was integrated with the application of 2 times botanical pesticides (10 DAS and 30 DAS) was the best treatment which was better able to increase the growth and yield of shallot true seeds compared to control and other treatments.

Key words: application of botanical pesticides, Biomatriconditioning, true seed

\footnotetext{
*Penulis untuk korespondensi, E-mail : sutariati69@yahoo.co.id
} 


\section{PENDAHULUAN}

Bawang merah (Allium ascalonicum L.) merupakan salah satu komoditas hortikultura yang sangat dikenal oleh masyarakat Indonesia. Setiap keluarga boleh dikatakan memanfaatkan bawang merah untuk memenuhi kebutuhan sehari-hari. Beberapa waktu terakhir, bawang merah menjadi perhatian berkenaan dengan fluktuasi harga dan pasokan. Produksi bawang merah di Sulawesi Tenggara pada tahun 2016 mencapai 891,9 ton dengan luas panen 154 ha (BPS Sultra, 2017). Tahun 2017 produksi bawang merah hanya mencapai 371,6 ton dengan luas panen 184 ha (BPS Sultra, 2018). Tahun 2018, dari hasil panen seluas 163 ha diperoleh 485,7 ton bawang merah (BPS Sultra, 2019). Selama kurun waktu tesebut, terjadi fluktuasi produksi. Walaupun luas panen meningkat, tidak menjamin kenaikan hasil yang signifikan.

Perbanyakan bawang merah secara generatif dapat memanfaatkan biji botani atau yang lebih dikenal dengan true seed. Pemilihan bahan tanam dan teknik budidaya yang tepat tentunya bisa menjadi solusi dalam menyelesaikan masalah keterbatasan benih bawang merah. Hanya saja, kualifikasi mutu benih baru dapat diketahui setelah benih tersebut diuji. Oleh karena itu, sangat penting dilakukan teknik perlakuan benih sebelum tanam. Sutariati et al. (2014) telah membuktikan bahwa aplikasi teknik invigorasi benih pratanam terbukti telah mampu mengatasi permasalahan hambatan mekanis pada benih, mempercepat dan menyeragamkan pertumbuhan serta meningkatkan persentase pemunculan kecambah dan bibit. Teknologi ini dapat diintegrasikan dengan agensia hayati atau biasa juga disebut biomatriconditioning.

Kendala lain dalam peningkatan produksi bawang merah adalah serangan penyakit layu fusarium. Pengembangan pestisida yang ramah lingkungan seperti pestisida nabati telah banyak dilakukan oleh para peneliti dalam mengendalikan serangan hama/penyakit. Sebagaimana hasil penelitian Setiyowaty et al. (2007) bahwa pengintegrasian perlakuan seed coating dengan fungisida Benomil dan tepung curcuma mampu menurunkan tingkat infeksi Colletotricum capsisi pada benih dan hipokotil cabai besar.

Penelitian ini bertujuan untuk menganalisis efektivitas perlakuan biomatriconditioning benih pratanam yang diintegrasikan dengan aplikasi pestisida nabati terhadap pertumbuhan dan hasil bawang merah true seed.

\section{METODE PENELITIAN}

\section{Tempat dan Waktu}

Perlakuan invigorasi benih (seed biomatriconditioning) dilakukan di Laboratorium Agroteknologi Universitas Halu Oleo dan lokasi penanaman dilaksanakan di Kel. Punggolaka, Kec. Puuwatu, Kendari, pada bulan Maret sampai dengan bulan Juli 2020.

\section{Bahan dan Alat}

Bahan-bahan yang digunakan dalam penelitian ini true seed varietas Lokananta, isolat rizobakteri indigenous Bacillus CKD061, Pseudomonas SWRII B02 dan Pseudomonas W2R06, aquades, agar, plastik wrap, kertas label, aluminium foil, etanol 70\%, Tryptone Soya Agar (TSA), serbuk arang sekam dan pestisida nabati Phymar C 67SL.

Alat-alat yang digunakan adalah gelas kimia, botol scott, oven, timbangan analitik, jarum ose, cawan petri, lampu bunsen, autoclave, laminair air flow cabinet, shaker, kamera, pot tray, polibeg, mistar, meteran dan sprayer.

\section{Prosedur Penelitian} berikut :

Prosedur pelaksanaan penelitian ini sebagai

\section{Perlakuan Benih dan Penyemaian}

Isolat rizobakteri ditumbuhkan dalam media TSA, diinkubasi selama 48 jam. Koloni bakteri yang tumbuh disuspensikan dalam aquades steril hingga mencapai kerapatan populasi $109 \mathrm{cfu} \mathrm{m}^{-1}$, setelah itu dicampur dengan serbuk arang sekam. Kemudian true seed dimasukkan ke dalam masingmasing campuran medium padatan lembab serbuk arang sekam yang telah mengandung suspensi bakteri, dilembabkan selama kurang lebih 12 jam. Benih dikeringanginkan dalam laminair air flow cabinet. Selanjutnya benih disemai dalam pot tray dengan media tanam campuran tanah humus dan arang sekam.

\section{Penanaman dan Aplikasi Pestisida Nabati}

Penanaman benih menggunakan polibag. Dalam satu polibeg ditanam satu tanaman dengan jarak tanam $20 \mathrm{~cm} \times 15 \mathrm{~cm}$. Aplikasi pestisida nabati mulai dilakukan pada 10 hari setelah tanam (HST), dengan cara menyemprotkan pestisida nabati ke seluruh daun hingga terlihat tetesan dari daun. Frekuensi aplikasi pestisida nabati sesuai perlakuan, interval $10 \mathrm{HST}$ (4 kali) dan interval 20 HST (2 kali). 


\section{Pemanenan}

Pemanenan dilakukan saat $90 \%$ daun telah menguning, tanaman rebah, leher umbi telah kosong dan umbi menyembul keluar.

\section{Rancangan Penelitian}

Rancangan penelitian yang digunakan adalah Rancangan Acak Kelompok (RAK) faktorial. Faktor pertama agensia hayati terdiri atas 4 taraf yaitu tanpa perlakuan invigorasi (B0), arang sekam + Bacillus CKD061 (B1), arang sekam + Pseudomonas SWRII B02 (B2) dan arang sekam +Pseudomonas W2R06 (B3). Faktor kedua aplikasi pestisida nabati terdiri atas 3 taraf yaitu tanpa aplikasi pestisida nabati (P0), 4 kali aplikasi (P1) dan 2 kali aplikasi (P2). Perlakuan yang diuji sebanyak 12 perlakuan dan diulang 3 kali, sehingga terdapat 36 unit perlakuan.

\section{Variabel Penelitian dan Analisis Data}

Variabel yang diamati adalah tinggi tanaman, jumlah daun, diameter batang, jumlah anakan, luas daun, laju asimilasi bersih, diameter umbi, berat segar umbi dan kesehatan tanaman. Data pengamatan dianalisis ragam dan data yang menunjukkan pengaruh nyata atau sangat nyata dilanjutkan dengan Uji Jarak Berganda Duncan pada taraf nyata $\alpha=0,05$.

\section{HASIL DAN PEMBAHASAN}

\section{Hasil}

\section{Tinggi Tanaman}

Pada pengamatan 2 MST (Tabel 1), perlakuan aplikasi pestisida nabati 4 kali (P1) terhadap $P$. SWRII B02 (B2) memberikan pengaruh yang tidak berbeda nyata dengan B.CKD061 (B1) dan P.W2R06 (B3). Sedangkan antara B.CKD061 (B1) dan P.W2R06 (B3), keduanya memberikan pengaruh yang berbeda nyata terhadap tinggi tanaman. Pada perlakuan aplikasi pestisida nabati 2 kali (P2), ketiga isolat menunjukkan pengaruh yang tidak berbeda nyata. Pada umur 4 MST (Tabel 2), perlakuan B0 (tanpa isolat), baik yang diaplikasikan pestisida nabati 2 kali maupun 4 kali pengaruhnya berbeda nyata. Pada umur 6 MST, rata-rata tinggi tanaman yang diberi perlakuan mandiri agens hayati, menunjukkan pengaruh yang berbeda nyata di antara semua perlakuan (Tabel 3).

Tabel 1. Hasil UJBD pengaruh interaksi agens hayati dengan aplikasi pestisida nabati terhadap rata-rata tinggi $(\mathrm{cm})$ tanaman bawang merah $2 \mathrm{MST}$

\begin{tabular}{|c|c|c|c|}
\hline \multirow{2}{*}{ Agens hayati (B) } & \multicolumn{3}{|c|}{ Aplikasi pestisida nabati } \\
\hline & P0 (kontrol) & P1 (4 kali) & P2 (2 kali) \\
\hline B0 (kontrol) & $16,87 \mathrm{c}$ & $17,47 \mathrm{c}$ & $15,55 \mathrm{~b}$ \\
\hline & $\mathrm{pq}$ & $\mathrm{p}$ & Q \\
\hline B1 (B. CKD061) & $19,68 \mathrm{ab}$ & $18,30 \mathrm{bc}$ & 19,43 a \\
\hline & $\mathrm{p}$ & $\mathrm{p}$ & $\mathrm{P}$ \\
\hline B2 (P. SWRII B02) & 20,65 a & $19,13 \mathrm{ab}$ & $19,55 \mathrm{a}$ \\
\hline $\mathrm{B} 3(P . \mathrm{W} 2 \mathrm{R} 06)$ & $\begin{array}{cc}p & \\
18,30 & b \\
q & \end{array}$ & $\begin{array}{c}\mathrm{q} \\
19,92 \mathrm{a} \\
\mathrm{p}\end{array}$ & $\begin{array}{c}\mathrm{Pq} \\
20,25 \quad \mathrm{a} \\
\mathrm{P}\end{array}$ \\
\hline
\end{tabular}

Keterangan : angka-angka yang diikuti oleh huruf yang sama pada kolom (a-b) dan baris (p-q) yang sama dinyatakan tidak berbeda nyata berdasarkan hasil UJBD pada taraf kepercayaan $95 \%$

\section{Jumlah Daun dan Jumlah Anakan}

Pengaruh mandiri terbaik diperoleh pada $B$. CKD061 (Tabel 4) karena dapat menghasilkan jumlah daun per tanaman tertinggi walaupun tidak berbeda nyata dengan $P$.SWRII B02 dan $P$.W2R06. Sedangkan perlakuan aplikasi pestisida nabati terbaik diperoleh pada perlakuan 2 kali aplikasi (P2) walaupun tidak berbeda nyata dengan perlakuan 4 kali aplikasi (P1). Sejalan dengan banyaknya jumlah daun, B.CKD061 juga menunjukkan jumlah anakan tertinggi. Hasil ini berbeda nyata dengan perlakuan $P$. SWRII B02 (B2), $P$. W2R06 (B3) dan kontrol (B0).

\section{Diameter Batang}

Batang tanaman bertambah besar seiring pertambahan umur tanaman. Tidak terjadi interaksi yang nyata dari kedua faktor perlakuan (Tabel 3). Secara mandiri, B. CKD061 (B1) menghasilkan ukuran diameter batang yang lebih besar, diikuti $P$. SWRII B02 (B2), P. W2R06 (B3) dan kontrol. Sedangkan pada perlakuan aplikasi pestisida nabati, pemberian 2 kali aplikasi pengaruhnya terhadap rata-rata diameter batang tanaman lebih baik daripada 4 kali aplikasi. 
J. Berkala Penelitian Agronomi 9 (2) : 105 - 113 (2021)

Tabel 2. Hasil UJBD pengaruh interaksi agens hayati dengan aplikasi pestisida nabati terhadap rata-rata tinggi $(\mathrm{cm})$ tanaman bawang merah umur 4 MST

\begin{tabular}{lccc}
\hline \multirow{2}{*}{ Agens hayati } & \multicolumn{3}{c}{ Aplikasi pestisida nabati } \\
\cline { 2 - 4 } & P0 (kontrol) & P1 (4 kali) & P2 (2 kali) \\
\hline B0 (kontrol) & $22,05 \mathrm{c}$ & $23,57 \mathrm{~b}$ & $21,58 \mathrm{c}$ \\
B1 (B. CKD061) & $\mathrm{pq}$ & $\mathrm{p}$ & $\mathrm{q}$ \\
& $29,45 \mathrm{a}$ & $29,12 \mathrm{a}$ & $30,58 \mathrm{a}$ \\
B2 (P. SWRII B02) & $\mathrm{p}$ & $\mathrm{p}$ & $\mathrm{p}$ \\
& $30,13 \mathrm{a}$ & $29,42 \mathrm{a}$ & $29,88 \mathrm{ab}$ \\
B3 (P. W2R06) & $\mathrm{p}$ & $\mathrm{p}$ & $\mathrm{p}$ \\
& $26,52 \mathrm{~b}$ & $28,30 \mathrm{a}$ & $28,42 \mathrm{~b}$ \\
& $\mathrm{q}$ & $\mathrm{p}$ & $\mathrm{p}$ \\
\hline
\end{tabular}

Keterangan : angka-angka yang diikuti oleh huruf yang sama pada kolom (a-c) dan baris (p-q) yang sama dinyatakan tidak berbeda nyata berdasarkan hasil UJBD pada taraf kepercayaan $95 \%$

Tabel 3. Hasil UJBD pengaruh mandiri agens hayati terhadap tinggi, diameter batang dan jumlah anakan tanaman bawang merah umur 6 MST

\begin{tabular}{lccc}
\hline \multicolumn{1}{c}{ Agens hayati } & $\begin{array}{c}\text { Tinggi tanaman } \\
(\mathrm{cm})\end{array}$ & $\begin{array}{c}\text { Diameter batang } \\
(\mathrm{cm})\end{array}$ & Jumlah anakan \\
\hline B0 (kontrol) & $29,88 \mathrm{~d}$ & $0,80 \mathrm{~b}$ & $1,06 \mathrm{c}$ \\
B1 (B. CKD061) & $42,67 \mathrm{a}$ & $1,07 \mathrm{a}$ & $1,39 \mathrm{a}$ \\
B2 (P. SWRII B02) & $41,16 \mathrm{~b}$ & $1,06 \mathrm{a}$ & $1,17 \mathrm{~b}$ \\
B3 (P. W2R06) & $37,11 \mathrm{c}$ & $1,05 \mathrm{a}$ & $1,17 \mathrm{~b}$ \\
\hline
\end{tabular}

Keterangan : angka-angka yang diikuti oleh huruf yang sama pada kolom yang sama (a-c) dinyatakan tidak berbeda nyata berdasarkan hasil UJBD pada taraf kepercayaan 95\%

Tabel 4. Hasil UJBD pengaruh mandiri agens hayati terhadap rata-rata jumlah daun (helai) tanaman bawang merah umur 4 dan 6 MST

\begin{tabular}{lcc}
\hline \multicolumn{1}{c}{ Agens hayati } & \multicolumn{3}{c}{ Umur Tanaman (MST) } \\
\hline & 4 & 6 \\
\hline B0 (kontrol) & $5,17 \mathrm{~b}$ & $6,39 \mathrm{~b}$ \\
B1 (B. CKD061) & $5,50 \mathrm{a}$ & $7,39 \mathrm{a}$ \\
B2 (P. SWRII B02) & $5,44 \mathrm{ab}$ & $6,72 \mathrm{~b}$ \\
B3 (P. W2R06) & $5,17 \mathrm{~b}$ & $7,11 \mathrm{a}$ \\
\hline & & \\
\hline Aplikasi pestisida nabati & 4 & 6 \\
\hline P0 (kontrol) & $5,13 \mathrm{~b}$ & $6,67 \mathrm{~b}$ \\
P1 (4 kali) & $5,33 \mathrm{ab}$ & $6,83 \mathrm{ab}$ \\
P2 (2 kali) & $5,50 \mathrm{a}$ & $7,21 \mathrm{a}$ \\
\hline
\end{tabular}

Keterangan: angka-angka yang diikuti oleh huruf yang sama pada kolom yang sama (a-b) dinyatakan tidak berbeda nyata berdasarkan hasil UJBD pada taraf kepercayaan $95 \%$

\section{Luas Daun}

Tabel 5 menunjukkan luas daun tanaman bawang merah mengalami peningkatan setiap minggunya. Tidak terjadi pengaruh interaksi perlakuan isolat bakteri dengan aplikasi pestisida nabati. Pada 4 MST, pengaruh mandiri $B$. CKD061
(B1) dan $P$. SWRII B02 (B2) memiliki total luas daun yang lebih tinggi dan berbeda nyata jika dibandingkan dengan pengaruh dari perlakuan $P$. W2R06 (B3) dan kontrol (B0). Selanjutnya pada umur 6 MST, masing-masing perlakuan menunjukkan pengaruh yang berbeda nyata 
terhadap rata-rata luas daun dan yang terbaik diperoleh pada perlakuan isolat $B$. CKD061 (B1). Pengaruh mandiri perlakuan aplikasi pestisida nabati tertinggi diperoleh pada perlakuan 2 kali aplikasi (P2) yang berbeda nyata dengan 4 kali alikasi (P1) dan tanpa aplikasi (P0).

\section{Laju Asimilasi Bersih (LAB)}

Tabel 6 menunjukkan pengaruh mandiri agens hayati terhadap LAB pada 6-4 MST tertinggi diperoleh pada B.CKD061 (B1) dan P. SWRII B02 (B2) dan berbeda nyata dengan perlakuan lainnya, sedangkan perlakuan aplikasi pestisida nabati tertinggi diperoleh pada 2 kali aplikasi (P2) yang tidak berbeda nyata dengan 4 kali aplikasi (P1). Interaksi agens hayati baik dengan perlakuan aplikasi maupun tanpa aplikasi pestisida nabati menghasilkan respon yang tidak berbeda nyata antara B1 dan B2, kecuali terhadap B3 dan kontrol (B0), hasilnya berbeda nyata (Tabel 7)

\section{Diameter Umbi dan Berat Segar Umbi}

Diameter umbi yang dihasilkan dari perlakuan $B$. CKD061 (B1) cenderung lebih besar daripada SWRII B02 (B2) dan $P$. W2R06 (B3) serta kontrol (tanpa perlakuan). Hal ini sejalan dengan pengamatan berat segar umbi (Tabel 8).

\section{Kesehatan Tanaman}

Selama penelitian berlangsung tidak ditemukan adanya gejala serangan layu fusarium pada tanaman bawang merah.

Tabel 5. Hasil UJBD pengaruh mandiri agens hayati terhadap rata-rata luas daun $\left(\mathrm{cm}^{2}\right)$ tanaman bawang merah umur 4 dan 6 MST

\begin{tabular}{lrlc}
\hline \multicolumn{1}{c}{ Agens hayati } & \multicolumn{3}{c}{ Umur Tanaman (MST) } \\
\hline & 4 & 6 \\
\hline B0 (kontrol) & 72,40 & $\mathrm{c}$ & $140,41 \mathrm{~d}$ \\
B1 (B. CKD061) & $103,69 \mathrm{a}$ & $217,52 \mathrm{a}$ \\
B2 (P. SWRII B02) & $104,55 \mathrm{a}$ & $207,06 \mathrm{~b}$ \\
B3 (P. W2R06) & $97,14 \mathrm{~b}$ & $197,91 \mathrm{c}$ \\
\hline \multicolumn{4}{c}{} \\
\hline Aplikasi pestisida nabati & 4 & & \\
\hline P0 (kontrol) & $87,58 \mathrm{c}$ & $177,01 \mathrm{c}$ \\
P1 (4 kali) & $94,76 \mathrm{~b}$ & $189,78 \mathrm{~b}$ \\
P2 (2 kali) & $101,00 \mathrm{a}$ & $205,39 \mathrm{a}$ \\
\hline
\end{tabular}

Keterangan: angka-angka yang diikuti oleh huruf yang sama pada kolom yang sama (a-c) dinyatakan tidak berbeda nyata berdasarkan hasil UJBD pada taraf kepercayaan $95 \%$

Tabel 6. Hasil UJBD pengaruh mandiri agens hayati terhadap rata-rata laju asimilasi bersih tanaman bawang merah $\left({\mathrm{g} . \mathrm{cm}^{-2}}^{-2}\right.$ minggu $\left.^{-1}\right)$ umur 6-4 MST

\begin{tabular}{lc}
\hline Agens hayati & Umur Tanaman (MST) \\
\hline & $6-4$ \\
\hline B0 (kontrol) & $0,031 \mathrm{c}$ \\
B1 (B. CKD061) & $0,046 \mathrm{a}$ \\
B2 (P. SWRII B02) & $0,044 \mathrm{a}$ \\
B3 (P. W2R06) & $0,039 \mathrm{~b}$ \\
\hline Aplikasi pestisida nabati & $6-4$ \\
\hline P0 (kontrol) & $0,036 \mathrm{~b}$ \\
P1 (4 kali) & $0,040 \mathrm{ab}$ \\
P2 (2 kali) & $0,044 \mathrm{a}$ \\
\hline
\end{tabular}

Keterangan: angka-angka yang diikuti oleh huruf yang sama pada kolom (a-c) yang sama dinyatakan tidak berbeda nyata berdasarkan hasil UJBD pada taraf kepercayaan $95 \%$. 
Tabel 7. Hasil UJBD pengaruh interaksi agens hayati dengan aplikasi pestisida nabati terhadap rata-rata laju asimilasi bersih tanaman bawang merah true seed umur 6-4 MST

\begin{tabular}{|c|c|c|c|}
\hline \multirow{2}{*}{ Agens hayati } & \multicolumn{3}{|c|}{ Aplikasi pestisida nabati } \\
\hline & P0 (kontrol) & P1 (4 kali) & P2 (2 kali) \\
\hline \multirow[t]{2}{*}{ B0 (kontrol) } & $0,037 \mathrm{c}$ & $0,037 \quad \mathrm{c}$ & $0,040 \quad a b$ \\
\hline & $\mathrm{p}$ & $\mathrm{p}$ & $\mathrm{p}$ \\
\hline \multirow[t]{2}{*}{ B1 (B. CKD061) } & 0,053 & 0,053 & 0,053 a \\
\hline & $\mathrm{p}$ & $\mathrm{p}$ & $\mathrm{p}$ \\
\hline \multirow[t]{2}{*}{ B2 (P. SWRII B02) } & 0,043 & 0,047 bc & 0,050 \\
\hline & $\mathrm{p}$ & $\mathrm{p}$ & $\mathrm{p}$ \\
\hline \multirow[t]{2}{*}{ B3 (P. W2R06) } & $0,077 \quad \mathrm{a}$ & $0,080 \quad \mathrm{a}$ & $0,037 \quad b$ \\
\hline & $\mathrm{p}$ & $\mathrm{p}$ & $\mathrm{q}$ \\
\hline
\end{tabular}

Keterangan : angka-angka yang diikuti oleh huruf yang sama pada kolom (a-c) dan baris (p-q) yang sama dinyatakan tidak berbeda nyata berdasarkan hasil UJBD pada taraf kepercayaan $95 \%$

Tabel 8. Hasil UJBD pengaruh mandiri agens hayati terhadap rata-rata diameter dan berat segar umbi bawang merah

\begin{tabular}{lcc}
\hline Perlakuan & Diameter umbi $(\mathrm{cm})$ & Berat segar umbi $(\mathrm{g})$ \\
\hline B0 (kontrol) & $2,12 \mathrm{c}$ & $6,05 \mathrm{c}$ \\
B1 (B. CKD061) & $3,24 \mathrm{a}$ & $14,21 \mathrm{a}$ \\
B2 (P. SWRII B02) & $3,05 \mathrm{~b}$ & $12,63 \mathrm{~b}$ \\
B3 (P. W2R06) & $2,99 \mathrm{~b}$ & $12,56 \mathrm{~b}$ \\
\hline
\end{tabular}

Keterangan: angka-angka yang diikuti oleh huruf yang sama pada kolom yang sama (a-c) dinyatakan tidak berbeda nyata berdasarkan hasil UJBD pada taraf kepercayaan $95 \%$

\section{Pembahasan}

Penggunaan isolat Bacillus CKD061 dan Pseudomonas SWRII B02 secara bersamaan dengan aplikasi pestisida nabati, menunjukkan laju pertumbuhan tinggi tanaman rendah, baik aplikasi pestisida nabati 2 kali maupun 4 kali dan bahkan lebih rendah tanpa perlakuan aplikasi pestisida nabati. Di awal pertumbuhan, laju pertumbuhan tanaman masih lebih banyak dipengaruhi oleh agens hayati. Pestisida nabati yang diaplikasikan pada tanaman bawang merah mulai 10 hari sejak pindah tanam, belum memberikan respon yang nyata. Seperti yang dilaporkan Djaenuddin dan Muis (2017), bahwa agens hayati yang diaplikasikan bersamaan dengan pestisida nabati menunjukkan hasil yang lebih rendah dibandingkan dengan tanpa diaplikasikan pestisida nabati. Bande et al. (2018), melaporkan bahwa penggunaan pestisida nabati dapat menghambat perkembangan Trichoderma sp. seiring dengan peningkatan dosis yang digunakan, akan tetapi pada di bawah konsentrasi 10\% pestisida nabati masih memenuhi syarat untuk diaplikasikan secara bersamaan.
Beda dengan B.CKD061 dan P.SWRII B02, P.W2R06 dapat bersinergi dengan aplikasi pestisida nabati dalam meningkatkan pertumbuhan dan hasil tanaman. Perlakuan kombinasi dari keduanya mampu memperbaiki struktur tanah dan cenderung mampu menyediakan asupan unsur hara untuk tanaman. Nasrun dan Nurmansyah (2015), melaporkan bahwa Bacillus sp. Bc94 dan P.fluorescens Pf55, serta kombinasi bahan aktif fungisida nabati sitronelal, geraniol, eugenol dan katekin mempunyai daya hambat yang tinggi terhadap pertumbuhan jamur R.microporus in vitro. Seperti yang dihasilkan dalam penelitian ini, $P$.W2R06 menunjukkan pengaruh interaksi yang positif. Jenis isolat yang berasal dari rizosfer tanaman mampu bersinergi dengan penggunaan pestisida nabati sehingga dapat meningkatkan pertumbuhan dan hasil tanaman bawang merah. Peningkatan tersebut diduga adanya suplai unsur hara yang berasal dari aktivitas agens hayati dan pestisida nabati. Pada fase pertumbuhan tanaman memerlukan unsur $\mathrm{N}$ dan $\mathrm{P}$ yang cukup terutama dalam pertumbuhan tinggi tanaman. Asupan unsur hara dari agens hayati diduga telah mencukupi 
kebutuhan unsur hara $\mathrm{N}$ dan $\mathrm{P}$ pada tanaman bawang merah sehingga dapat menghasilkan pertumbuhan vegetatif yang baik terutama pada tinggi tanaman. Seperti yang dilaporkan Ilham et al. (2014) dan Sutariati et al. (2018), bahwa bakteri pemacu pertumbuhan tanaman dapat memfiksasi nitrogen dari udara dan melarutkan fosfat yang terserap oleh logam berat di dalam tanah. Memasuki umur 6 MST, nampak perbedaan yang nyata dari ketiga jenis agens hayati terhadap tinggi tanaman. Tanaman yang diberi perlakuan biomatiriconditioning B.CKD061, lebih tinggi dibandingkan isolat lainnya dan kontrol. Penelitian ini sejalan dengan Darsan et al. (2018), teknik biomatriconditioning juga mampu meningkatkan viabilitas dan vigor benih padi sawah. Perlakuan terbaik untuk varietas Inpari 10 adalah Bacillus CKD061 + serbuk arang sekam. Lanjut Sutariati et al. (2014) bahwa rizobakteri yang diintegrasikan dengan matriconditoning meningkatkan pertumbuhan dan produksi tanaman tomat. Handayani et al. (2019), juga telah membuktikan bahwa kombinasi matriconditioning dengan rizobakteri dapat meningkatkan pertumbuhan tanaman Sorgum. Selain itu juga keberadaan matriconditioning berperan sebagai media pembawa bakteri (Rakian et al., 2018) sehingga mampu mengefektifkan kinerja bakteri (agens hayati) untuk meningkatkan pertumbuhan dan hasil tanaman.

Pada pengamatan jumlah anakan, diameter dan berat umbi isolat Bacillus CKD061 memberikan hasil yang terbaik. Diduga kemampuan agens hayati ini dalam menyediakan hara fosfor menjadi bentuk terlarut lebih optimal dibandingkan dengan Pseudomonas SWRIIB02 dan Pseudomonas W2R06. Suplay fosfor dari CKD061 menghasilkan tanaman dengan sebaran akar yang lebih luas membuat tanaman bawang merah lebih banyak menyerap hara untuk pengisian umbi. Selain itu campuran sekam bakar pada media tanam juga mendukung perkembangan umbi. Umbi akan berkembang sempurna pada tanah yang porous dan gembur (Rabinowitch and Brewster, 1990).

Agens hayati dapat meningkatkan pertumbuhan tanaman melalui mekanisme peningkatan unsur hara di dalam tanah maupun memproduksi hormon yang dapat memacu pertumbuhan tanaman. Sutariati et al. (2012) bahwa Bacillus CKD061 dapat memfiksasi nitrogen dari udara, melarutkan fosfat dan memproduksi hormon IAA. Adanya aktivitas IAA dalam daun tanaman tidak berpengaruh nyata antar perlakuan agens hayati terhadap pertumbuhan tinggi tanaman, luas daun dan diameter batang. Perbedaan yang tidak nyata antar perlakuan agens hayati diduga disebabkan karena masing-masing isolat bakteri yang digunakan mampu menginduksi hormon IAA. Selain itu fosfor yang terlarut dapat diserap oleh tanaman sehingga berimplikasi terhadap peningkatan hasil tanaman seperti pada penelitian ini. Razaq et al. (2017), mengungkapkan bahwa fosfor berperan membantu dalam pembelahan sel, aktivasi enzim dan metabolisme karbohidrat. Fosfor merupakan unsur penting dari senyawa yang kaya energi dan menjadi konstituen asam nukleat (DNA, RNA).

Berlangsungnya fotosintesis dipengaruhi oleh jumlah dan luas daun. Daun tanaman dapat menyerap energi cahaya berupa gelombang eletromagnetik dengan bantuan klorofil daun tanaman, $\mathrm{CO}^{2}$ dari udara bebas dan air di dalam tanah sehingga membentuk karbohidrat (fotosintat) yang ditranslokasikan ke seluruh bagian tanaman (Salisbury and Ross, 1995). Banyaknya fotosintat yang dihasilkan akan sangat berguna untuk ketegaran tanaman dan pembesaran umbi. Sitompul dan Guritno (1995) dalam Koryati et al. (2021) menyatakan bahwa laju pertumbuhan relatif merupakan peningkatan berat kering tanaman dalam suatu interval waktu, erat hubungannya dengan berat awal tanaman. Peningkatan luas daun berbanding lurus dengan bertambahnya laju asimilasi tanaman yang terakumulasi dalam bentuk berat kering tanaman. Pada pengamatan luas daun umur $4 \mathrm{MST}$ dan $6 \mathrm{MST}$, pengaruh mandiri agens hayati B.CKD061 dan P.SWRII B02 lebih tinggi dibandingkan perlakuan lainnya. Sedangkan pada perlakuan aplikasi pestisida nabati, frekuensi 2 kali aplikasi lebih baik dibandingkan 4 kali. Hal ini sejalan dengan nilai laju asimilasi bersih yang dihasilkan dari perlakuan tersebut. Peningkatan hasil tanaman bawang merah diduga erat hubungannya dengan jumlah daun, luas daun dan berat kering tanaman seperti yang dihasilkan dalam penelitian ini. Yusuf et al. (2020) melaporkan bahwa jumlah daun, luas daun dan berat kering tanaman berkorelasi positif dengan produktivitas tanaman. Selain isolat bakteri, aplikasi pestisida nabati diduga turut menyuplai hara yang lebih mudah diserap oleh tanaman sehingga dapat dimanfaatkan langsung pada fase pertumbuhan vegetatif tanaman. Formula pestisida nabati yang merupakan ekstrak kulit biji mete juga mengandung unsur $\mathrm{Ca}$. Kedua bahan ini selain berperan meningkatkan ketahanan tanaman terhadap OPT, unsur $\mathrm{Ca}$ turut membantu translokasi pati dan distribusi fosfor di dalam tubuh tanaman. Sakinah et al. (2013) melaporkan bahwa penggunaan kompos berbahan dasar kulit biji mete memberikan 
pengaruh yang lebih baik terhadap pertumbuhan bibit mete dan serapan hara dibandingkan kontrol.

Pada penelitian ini tidak menunjukkan adanya gejala penyakit layu fusarium pada tanaman bawang merah, sehingga belum dapat diketahui efektivitas perlakuan aplikasi pestisida nabati dalam mengendalikan serangan layu fusarium. Namun terdapat efek lain yang timbul dari penggunaan pestisida nabati ini, yaitu dapat memperlambat pertumbuhan dan hasil tanaman seiring dengan peningkatan frekuensi aplikasinya. Hasil penelitian menunjukkan bahwa perlakuan aplikasi pestisida nabati sebanyak 2 kali dengan interval waktu 20 hari menghasilkan pertumbuhan yang lebih tinggi dibandingkan dengan 4 kali aplikasi dengan interval waktu 10 hari dan kontrol. Hal ini sejalan dengan penelitian Gusnawaty et al. (2014), bahwa frekuensi aplikasi pestisida nabati Phymar C 117 sebanyak 2 kali dengan interval waktu 16 hari merupakan frekuensi aplikasi terbaik karena menghasilkan persentase kesembuhan tanaman jeruk terbesar yakni 72,98\% (16 HSA) dan 97,92\% (32 HSA). Penyebab tidak adanya kejadian penyakit Layu Fusarium pada penelitian ini selain diduga karena bahan tanam berasal dari biji yang dianggap tidak berpotensi tertular patogen (deskripsi bawang merah Lokananta) dan tanpa perlakuan infeksi patogen pada media tanam, juga diduga karena penanaman menggunakan polibeg. Budidaya tanaman dalam polibeg cenderung memiliki ketahanan yang lebih baik daripada ditanam pada lahan terbuka. Komposisi media tanam pada masing-masing polibeg jadi lebih terkontrol dan nutrisi tanaman dapat langsung diserap oleh akar, tidak ada pengaruh dari luar.

\section{KESIMPULAN}

Biomatriconditioning benih menggunakan isolat Bacillus CKD061 yang diintegrasikan dengan aplikasi pestisida nabati 2 kali (10 HST dan 30 HST) merupakan perlakuan terbaik yang lebih mampu meningkatkan pertumbuhan dan hasil bawang merah true seed dibandingkan dengan kontrol dan perlakuan lainnya.

\section{REFERENSI}

Bande, L.O.S., Mariadi, Gusnawaty, H.S., Nuriadi, Trisulpa and Rahmania, 2018. Botanical Pesticides Effect from Shells of Bean's Cashew Nut on Biological Agents of Trichoderma sp. and Gliocladium sp. International Conference on Agriculture,
Environment, and Food Security. Earth and Environmental Science 122 (2018) 012047 doi:10.1088/1755-1315/122/1/ 012047.

BPS Sultra, 2017. Luas Panen dan Produksi Sayur Buah Semusim di Sultra Tahun 2016 - 2017. https://sultra.bps.go.id/statictable/2019/03/27/ 2134/luas-panen-dan-produksi-sayur-buahsemusim-di-sultra-tahun-2016---2017.html.

BPS Sultra, 2018. Luas Panen Tanaman Sayur Buah Semusim Provinsi Sulawesi Tenggara (Hektar) 2014-2018.

https://sultra.bps.go.id/statictable/2019/10/07/ 2573/luas-panen-tanaman-sayur-buahsemusim-provinsi-sulawesi-tenggara-hektar2014-2018.html.

BPS Sultra, 2019. Produksi Tanaman Sayur Buah Semusim Provinsi Sulawesi Tenggara (Kuintal) 2014-2018.

https://sultra.bps.go.id/statictable/2019/10/07/ 2570/produksi-tanaman-sayur-buahsemusim-provinsi-sulawesi-tenggara-kuintal2014-2018.html.

Darsan S., Sutariati G.A.K., Mamma S., 2018.

Peningkatan Viabilitas dan Vigor Benih Padi Sawah (Oryza sativa L.) dengan Teknik Biomatriconditioning. Jur.Agroekotek 10 (1) : 53 - 64, Juli 2018. Universitas Sultan Ageng Tirtayasa. Serang-Banten, https://jurnal.untirta.ac.id/index.php/jav/articl e/view/5465.

Djaenuddin, N dan A. Muis, 2017. Efektivitas Biopestisida Bacillus subtilis $\mathrm{BNt} 8$ dan Pestisida Nabati untuk Pengendalian Penyakit Hawar Pelepah dan Upih Daun Jagung. $J$. HPT Tropika. ISSN 1411-7525. Vol. 17, No. 1: 53 - 61, Maret 2017.

http://jhpttropika.fp.unila.ac.id/index.php/jhpt tropika/article/view/364.

Gusnawaty H.S., Mariadi dan Muliana, 2014. Pengaruh Perbedaan Frekuensi Aplikasi Pestisida Nabati Phymar C 711 terhadap Kesembuhan Penyakit Busuk Batang Diplodia (Botryodiplodia theobromae Pat.) pada Tanaman Jeruk (Citrus reticulata L.). Agriplus, Vol 24, No 1 p.1-8. http://ojs.uho.ac.id/index.php/agriplus/article/ view/53.

Handayani F., Sutariati, G.A.K., Madiki A., 2019. Biomatriconditioning Benih denigan Rizobakteri untuk Meningkatkan Pertumbuhan dan Hasil Tanaman Sorgum 
(Sorghum bicolor L.). Jurnal Agroteknologi dan Ilmu Pertanian 4(1):52. https://ojs.uma.ac.id/index.php/agrotekma/a rticle/view/2949/2350

Ilham, Darmayasa, I.B.G., Nurjaya, I.G.M.O., Kawuri, R., 2014. Isolasi dan Identifikasi Bakteri Pelarut Fosfat Potensial pada Tanah Konvensional dan Tanah Organik. Jurnal Simbiosis, II (1) :173-183. ISSN: 23377224, Maret 2014. https://docplayer.info/46712844-Isolasidan-identifikasi-bakteri-pelarut-fosfatpotensial-pada-tanah-konvensional-dantanah-organik.html.

Koryati, T., Purba, D.W., Surjaningsih, D.R., Herawati, J., Sagala, D., Purba, S.R., Khairani, M., Amartani, K., Sutrisno, E., Panggabean, N.H., Erdiandini, I., Aldya, R.F., 2021. Fisiologi Tumbuhan. Cetakan 1, 204 halaman, Januari 2021, halaman 134135. Penerbit Yayasan Kita Menulis, Kota Medan. ISBN 978-623-6840-38-2. https://tinyurl.com/ys84b3ju.

Nasrun dan Nurmansyah, 2015. Potensi Rizobakteria dan Fungisida Nabati untuk Pengendalian Penyakit Jamur Akar Putih Tanaman Karet. J. TIDP 2(2), 61-68. https://pdfs.semanticscholar.org/1de9/8240 9a765319479f5b0ca7cc96ec6c3f175b.pdf.

Rabinowitch, H.D. and Brewster, J.L., 1990. Onions and Allied Crops Botany, Physiology and Genetics 1st Edition: 287 ISBN $9781351075169 \quad$ Subjects Environment \& Agriculture. 22 December 2017. CRC Press.

https://www.taylorfrancis.com/books/edit/1 0.1201/9781351075169/onions-alliedcrops-haim-rabinowitch-james-brewster

Rakian, T.C., Karimuna L., Taufik, M., Sutariati, G.A.K., Muhidin and Fermin U., 2018. The Effectiveness of Various Rhizobacteria Carriers to Improve The Shelf Life and The Stability of Rhizobacteria as Bioherbicide. International Conference on Agriculture, Environment and Food Security. IOP Conf. Series: Earth and Environmental Science, 122 (2018) 012032. doi :10.1088/1755$1315 / 122 / 1 / 012032$.

Razaq, M., Zhang, P., H., Shen H.L., Salahuddin, 2017. Influence of Nitrogen and Phosphorous on The Growth and Root Morphology of Acer Mono. Plos One. 12(2): e0171321 p.1-13. https://journals.plos.org/plosone/article?id=1 0.1371 /journal.pone. 0171321 .

Sakinah, Nur., Hasjim, M., Hariyadi, Manohara D., 2013. Pemanfaatan Limbah Kulit Biji Mete sebagai Pupuk Organik untuk Meningkatkan Pertumbuhan Bibit Tanaman Mete. Jurnal Agronomi. Universitas Dayanu Ikhsanuddin, Baubau-Indonesia 42 (3) : 250 255 (2014).

https://journal.ipb.ac.id/index.php/jurnalagro nomi/article/view/9184.

Salisbury, F.B and Ross, C.W., 1995. Fisiologi Tumbuhan Jilid 3. Diah R. Lukman (penerjemah), ITB Press, Bandung.

Setiyowati H., Surahman, M., Wiyono S.,. 2007. Pengaruh Seed Coating dengan Fungisida Benomil dan Tepung Curcuma terhadap Patogen Antraknosa Terbawa Benih dan Viabilitas Benih Cabai Besar (Capsicum annum L.) Bul. Agron. (35) (3) 176 - 182. https://journal.ipb.ac.id/index.php/jurnalagr onomi/article/download/1328/428.

Sutariati G.A.K., Safuan L.O., Wahab A., 2012. Karakter Fisiologis dan Kemangkusan Rizobakteri Indigenus Sulawesi Tenggara sebagai Pemacu Pertumbuhan Tanaman Cabai. $J$ Hort. 22(1):57-64. http://dx.doi.org/10.21082/jhort.v22n1.2012. p57-64.

Sutariati, G.A.K., Madiki, A., Khaeruni, A., 2014. Integrasi Teknik Invigorasi Benih dengan dengan Rizobakteri untuk Pengendalian Penyakit dan Peningkatan Hasil Tomat. Jurnal Fitopatologi Indonesia, 10 (6) p.188194. https://doi.org/10.14692/jfi.10.6.188.

Sutariati, G.A.K., Rakian, T.C., Khaeruni, A., Ratna, 2018. The Potential of Indigenous Rhizobacteria Isolated from Wakatobi Rocky Soil as Plant Growth Promoting of Onions. Bioscience Research, 15(4):3768-3774. https://www.isisn.org/BR15(4)2018/37683774-15(4)2018BR18-465.pdf

Yusuf, M., Hasid, R., Kandari, A.M., Sarawa, Madiki A., Karimuna, L., 2020. Pertumbuhan dan Hasil Tanaman Kacang Tanah (Arachis hypogaea L.) dengan Aplikasi Pupuk Organik berbasis Ampas Sagu di Lahan Sub Optimal. J. Berkala Penelitian Agronomi 7 (2) : $74-81$. http://ojs.uho.ac.id/index.php/agronomi/articl e/view/9728. 